\title{
Effects of Water Deficit and Rehydration on the Polar Lipid and Membranes Resistance Leaves of Phaseolus vulgaris L. Cv. Pérola
}

\author{
Raimundo Rômulo Martins Júnior ${ }^{1 *}$, Micheline Soares Costa Oliveira ${ }^{2}$, Maria Ary \\ Baccache $^{2}$ and Fernando Monteiro de Paula ${ }^{2}$ \\ ${ }^{1}$ Laboratório de Eletroquímica; Departamento de Ciência de Materiais; Universidade Federal de Pernambuco - \\ UFPE; Cidade Universitária; 50670-901; rrmj@ufpe.br; Recife - PE - Brasil. ${ }^{2}$ Departamento de Bioquímica e \\ Biologia Molecular; Universidade Federal do Ceará-UFC; 60001-970; Fortaleza - CE - Brasil
}

\begin{abstract}
Bean leaves (Phaseolus vulgaris L.) cv. Pérola were used to evaluate the water deficit effects in polar lipids composition and in the electric conductivity. The results showed that the water deficiency a effected in the electrolytes loss which increased gradually in response to water deficit. This suggested a compartimentalization loss, due to the structural cellular membranes elements degradation. Total lipids contents decreased by reason of the water stress action. The polyunsaturated fatty acid contents (linoleic and linolenic acids) suffered a decrease while saturated fatty acid (palmitic and stearic acids) increased. The imbalance in the fatty saturated/unsaturated acid relation led to a reduction in the unsaturation index. The electrolytes loss increase related whith the to polyunsaturated fatty acid contents reduction suggested a larger dehydrated plants vulnerability, leading to a consequent loss in the productivity.
\end{abstract}

Key words: Polar lipids; membranes resistance; water stress

\section{INTRODUCTION}

Leguminosae are important sources of proteins, calories, vitamins and minerals. They constitute an integral part of human diet and can also be used as animal forage. Bean is considered a leguminous plant of great social and economic importance and water deficit is one of the main factors which limit the vegetable growth. According to Kramer and Boyer (1995), species submitted to areas where water stress frequently occurs, develop mechanisms to facilitate a larger environmental adaptation. Protoplasmatic resistance level results from the cellular membranes integrity conservation and cellular compartimentalization (El-Tohamy et al., 1999). There are different mechanisms, which allow plants a high resistance to water deficit. Cellular membranes damage can be verified through different procedures, for example, directly by electronic microscopy (Sajo and Machado, 2001; Douliez, 2004) and indirectly by electrolytes leakage test (Ismail et al., 2000; Thiaw and Hall, 2004). The electrolytes leakage test can evaluate damages shown by the cellular membranes, where ions flow raise occurs in consequence of a larger cellular membranes permeability (Ismail et al., 1997). A cellular water reduction can induce modifications in cellular

\footnotetext{
${ }^{*}$ Author for correspondence
} 
membranes permeability and fluidity due to bilayer fatty acids destruction in the membranes (Marrink et al., 1996). A decrease in the unsaturation degree means a cellular membranes rigidity increase (Monteiro de Paula et al., 1993; Costa Oliveira, 2001). Lipids are also the structural elements responsible for the selective permeability membranes. Therefore, the maintenance of these molecules physical and chemical properties renders the biological membranes functional. Polar lipids are essential constituents of cellular membranes and play a fundamental function in its structure and metabolism (Dakma et al., 1995).

Water stress, as well as other stress types, can modify lipids membranes composition and consequently alter cellular metabolic activities compartimentalization (Liljenberg et al., 1992). The fatty acid nature which composes plants lipids membranes depends on the temperature and water availability intimately (Ahmed et al., 1993; Kizis et al., 2001). On the other hand, those factors play a very important role in the maintenance of the fatty acid functional configuration (Dakma et al., 1995; Hamrouni et al., 2001; Kizis et al., 2001). Water deficit can modify plasmatic membranes lipids as much as different cytoplasmatic organelles affect their function, as well as the proper cellular metabolism. Alterations in lipids composition of the chloroplasts membranes can affect different plastidials lipids in an important way, such as the galactolipids - MGDG (monogalactosyl-diacylglycerol) and DGDG (digalactosyl-diacylglycerol), the sulfolipid SQDG (sulfoquinovosyl-diacylglycerol) and the phosfolipid - PG (phosphatidylglycerol) (NavariIzzo et al., 1989; Monteiro de Paula et al., 1990; Lauriano et al., 2000). The foliar membranes tyically possess high contents of galactolipids, differently of animal cells membranes and nongreen plants tissues (Ferrari-Iliou et al., 1984; Pham Thi et al., 1987). Raising in saturated fatty acids grade and the reduction in unsaturated fatty acids induce membranes structural modifications. The cellular membranes which possess an unsaturated level (the relation between saturated and unsaturated fatty acid) changed in environmental stresses function, like water stress, are consequently modified in the selective permeability as in the enzymes compartimentalization (El-Tohamy et al., 1999). The galactolipids unsaturation level can be reduced due to an increase or acceleration of the linoleic and linolenic acids degradation process, induced by the water deficiency (Chetal et al., 1981; Ferrari-Iliou et al., 1984; Martin et al., 1986; Navari-Izzo et al., 1989; Monteiro de Paula et al., 1990; Bigogno et al., 2002). In order to know about the better bean seedding behavior (Phaseolus vulgaris L. cv. Pérola) under water deficit conditions and after its rehydration, a study was done to find on the relationship between the lipids structure which constituted the cellular membranes (what corresponded about $40 \%$ of dry weight) and the resistance to cellular membranes levelly.

\section{MATERIAL AND METHODS}

\section{Vegetable material and cultivation conditions}

Bean seeds (Phaseolus vulgaris L.) cv. Pérola, produced in Jardim Clonal CCP, Pacajus - CE, EMBRAPA - Agroindústria Tropical, were cultivated in a greenhouse (air relative humidity from 70 to $74 \%$ and temperature of $29.1 \pm 0.3{ }^{\circ} \mathrm{C}$ ), in plastic vases containing vermiculit and water in the proportion of 2:1 (v/v). Forty plants were cultivated, being a plant for pail. The water dissipated by evaporation and/or perspiration was daily restituted in the same proportion. After 40 days of germination, the plants were separated and divided in two lots (three repetitions each): one of them was kept irrigated (irrigated treatment or control) until the experiment, and the other was submitted to drought through withholding water (stressed treatment) for up to 45 days. The water potential (MPa) of each plant was determined by the pressure chamber method (Scholander, 1964). The water potential $(\psi)$ for the treatment control was kept stable as $\psi=-0.4$ to $-0.5 \mathrm{MPa}$ during the whole experiment. For the stressed treatment, the water potential diminished to every day after irrigation suspension, $\psi \leq-7.0 \mathrm{MPa}$ for 45 stress days, characterizing a severe stress. The stressed treatment plants after 45 days were rehydrated for six days, and their water potentials were restored $(\psi=-0.4$ to $-0.5 \mathrm{MPa})$ in just two days remaining constant until the experiment.

\section{Membrane Resistance Test}

The cellular membranes integrity was measured through the fresh foliate tissue disks. Twenty disks (three leaves) of $1 \mathrm{~cm}$ of diameter were put 
into a $20 \mathrm{~mL}$ distilled water in the test tube and kept in the darkness (to prevent electrolytes loss induced by the light). The disks were washed three times with the intervals of 15 minutes in order to eliminate the electrolytes adsorbed on disks surface as well as cells fragments produced during the disks process. After the last wash, the disks were left in repose for an hour at $25^{\circ} \mathrm{C}$ in the darkness. The electric conductivity (EC) was measured during a period of $24 \mathrm{~h}$, every two hours. All results are means of three replicates. The conductivity measures were done according to Dassa-Girard method (1987) using a Lutron-CD4302 conductive mechanism.

\section{Lipid analysis}

Leaves were kept in boiling distilled water to 2 min to inactivate the phospholipases of the tissues (Benson, 1964) and lipids were extracted in the chloroform-methanol (James et al., 1966; Allen and Good, 1971). Lipids were separeted by thin layer chromatography (Lepage, 1967). The total lipid extracts and the different classes of fatty acids were quantified by the liquid-gas chromatography using heptadecanoic acid as internal standard (for details about the methods, see Pham Thi et al., 1985).

All results are means of three replicates \pm SD.

\section{Unsaturated level}

According to Pham Thi et al. (1985), the unsaturated index can be calculated from the following equation:

Unsaturation Index =

$$
\frac{(1 \times \% 18: 1)+(2 \times \% 18: 2)+(3 \times \% 18: 3)}{100}
$$

where $18: 1,18: 2$ and 18:3, represent the oleic, linoleic and linolenic acids, respectively.

\section{RESULTS AND DISCUSSIONS}

\section{Membrane Resistance}

The membrane resistance measured by the electrolytes loss revealed accentuated losses in the stressed treatment plants, with a significant increase of until $175 \%$ (in $24 \mathrm{~h}$ ) in the electrolytes loss in the irrigated plants (Fig. 1). Even after rehydration, this tendency didn't change (Fig. 2), and the plants submitted to water deficit presented conductivity values highs than those of the irrigated plants. An increase in the permeability of the plants submitted to water deficit could have occurred in response to an increased passive diffusion, probably due to the lipids membranes destruction. Thus, more accentuated electrolytes losses come, consequently reflect, in the can integrity cellular membranes loss.

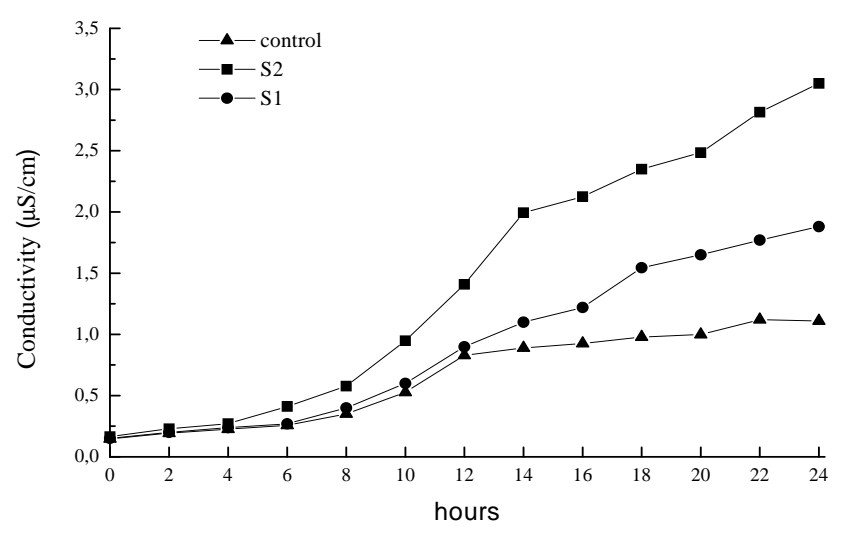

Figure 1 - Electric conductivity as a function of time from disks leaves in Phaseolus vulgaris L. cv. Pérola., under Control conditions $(\boldsymbol{\Delta})$, well-hydrated plants; S1, moderately stressed plants (20days) (•) and severely stressed plants (45 days) (๘) conditions 


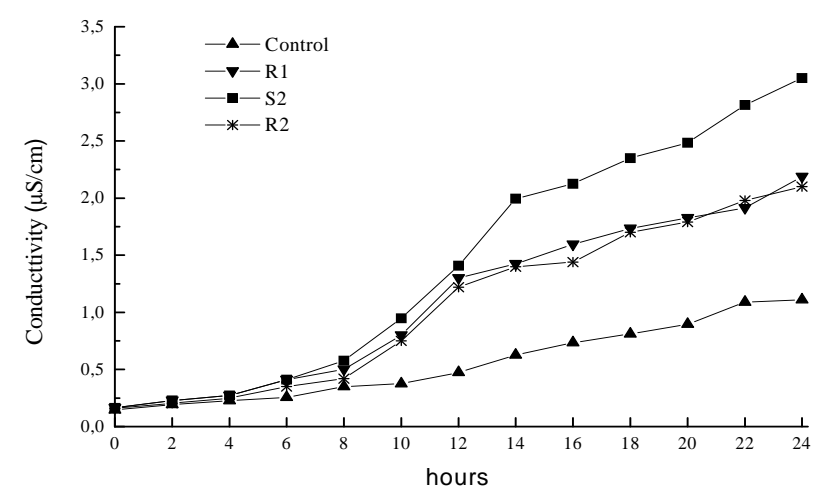

Figure 2 - Electric conductivity as a function of time from disks leaves in Phaseolus vulgaris L. cv. Pérola, under Control conditions ( $\boldsymbol{\Delta})$, well-hydrated plants; S2 (ם), severely stressed plants for 45 days; R1 ( $)$, plants rehydrated for 2 days; R2 $(*)$, plants rehydrated for 6 days.

\section{Total leaf lipid content}

Extraction method of Allen and Good (1971) demonstrated that leaves polar lipid contents were in the range of $19 \mathrm{mg} / \mathrm{g}$ DW (dry weight) for Phaseolus vulgaris L. cv. Pérola (Fig. 3).
Progressive dehydration resulted in a steady and steep reduction, so that in the severely stressed plants (45 days), they were very low. After 2 and 6 days of rehydration, the lipid content was not completely recovered.

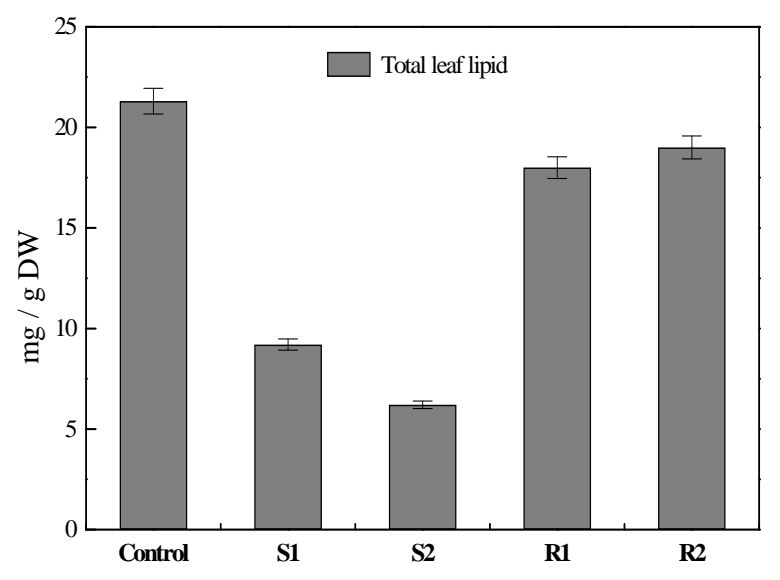

Figure 3 - Effects of water stress and rehydration on the total lipid content of Phaseolus vulgaris L. cv. Pérola leaves (in mg/g DW). Control, well hydrated plants; S1, moderately stressed plants (20 days of dehydration); S2, severely stressed plants (45 days of dehydration); R1, plants rehydrated for 2 days; R2, plants rehydrated for 6 days.

\section{Effect of water deficit on fatty acids and on} total leaf lipids

The foliate beans membranes total fatty acid contents analysis revealed a typical composition of superior vegetables chlorophyll tissues, and a high contents in unsaturated fatty acid, mostly linolenic acid (18:3) (Ferrari et al., 1984; Navari-Izzo et al., 1989; Monteiro de Paula et al., 1990). Linolenic acid constitutes the main galactolipids (MGDG and DGDG) component of thilacoids membranes, being responsible for the great fluidity of these membranes. The reductions in the contents of 
MGDG and DGDG (Fig. 4) these directly related to the decreases in the polyunsaturated fatty acid content. The capillary column gaseous chromatography showed the presence of the following fatty acid: palmitic acid (16:0), stearic acid (18:0), oleic acid (18:1), linoleic acid (18:2) and linolenic acid (18:3). The total leaves fatty acid composition was affected by the drought. There was an increase in palmitic (16:0) and stearic acids (18:0) and a decrease in oleic (18:1), linoleic (18:2) and linolenic acids (18:3) in accordance with the stress severity degree (Table 1). The water deficit led to some fatty acid contents modifications, inducing saturation increases and unsaturation index decreases (Fig. 5). The stress treatment in plants presented unsaturation index lower than the control plants. After 2 and 6 rehydration days, the unsaturation index of plants submitted to water deficit wasn't recovered yet. The polar lipids degradation, associated with an alteration in the saturated/unsaturated fatty acid relation and a reduction in unsaturated index come explain the electrolytes biggest loss and consequent dehydrated plants cellular membranes nonstructuralization.

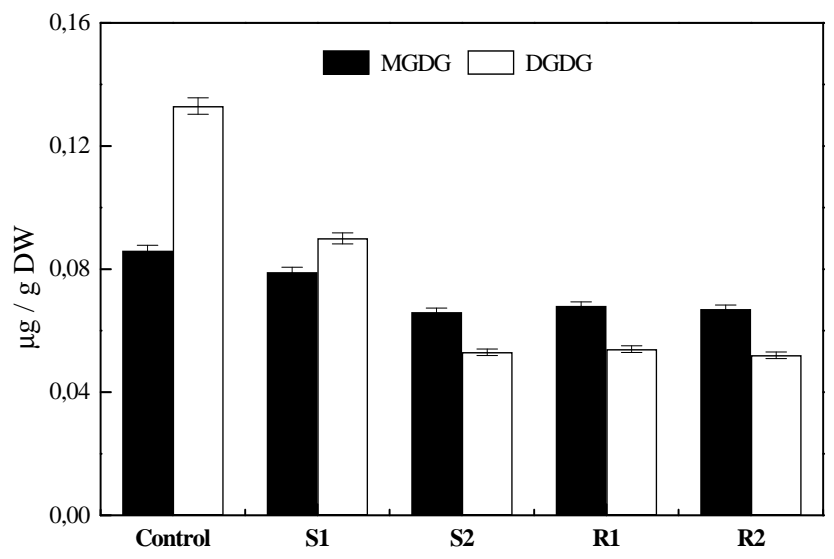

Figure 4 - MGDG and DGDG content (in $\mu \mathrm{g} / \mathrm{g}$ DW ) from membranes lipids in Phaseolus vulgaris L. cv. Pérola leaves under Control conditions, well hydrated plants; S1, moderately stressed plants (20 days of dehydration); S2, severely stressed plants (45 days of dehydration); R1, plants rehydrated for 2 days; R2, plants rehydrated for 6 days.

Table 1 - Water-deficit and rehydration effect on the fatty acid composition of total lipids in Phaseolus vulgaris L. cv. Pérola.

\begin{tabular}{lccccc}
\hline \multirow{2}{*}{ Treatment } & \multicolumn{5}{l}{ Fatty acid (weight as \% of total lipids) } \\
\cline { 2 - 6 } & \multicolumn{1}{l}{$\mathbf{1 6 : 0}$} & $\mathbf{1 8 :} \mathbf{0}$ & $\mathbf{1 8 : ~}$ & $\mathbf{1 8 : 2}$ & $\mathbf{1 8 : ~ 3}$ \\
\hline Control & $14.2 \pm 1.5$ & $2.1 \pm 1.7$ & $4.8 \pm 1.6$ & $24.5 \pm 2.2$ & $54.4 \pm 2.7$ \\
S1 & $15.9 \pm 1.4$ & $4.7 \pm 1.8$ & $4.5 \pm 2.0$ & $23.1 \pm 2.9$ & $51.8 \pm 2.5$ \\
S2 & $28.5 \pm 1.5$ & $21.9 \pm 1.0$ & $3.9 \pm 2.1$ & $13.7 \pm 1.7$ & $32.0 \pm 2.7$ \\
R1 & $13.5 \pm 1.3$ & $3.4 \pm 1.9$ & $8.5 \pm 1.9$ & $20.1 \pm 1.2$ & $53.1 \pm 1.1$ \\
R2 & $13.8 \pm 1.8$ & $2.0 \pm 1.7$ & $4.2 \pm 0.8$ & $28.0 \pm 1.3$ & $51.7 \pm 1.8$ \\
\hline
\end{tabular}


The polyunsaturated fatty acid content reduction induces metabolic alterations in the cellular membranes. It, accompanied by the saturated fatty acid content increase, conditions a larger rigidity in cellular membranes. Hence, alterations in plants cellular membranes fatty acid composition and content submitted to water deficit would supposedly render these membranes less efficient in enzymatic reactions, inducing precocious senescense process and vegetable productivity consequent loss.

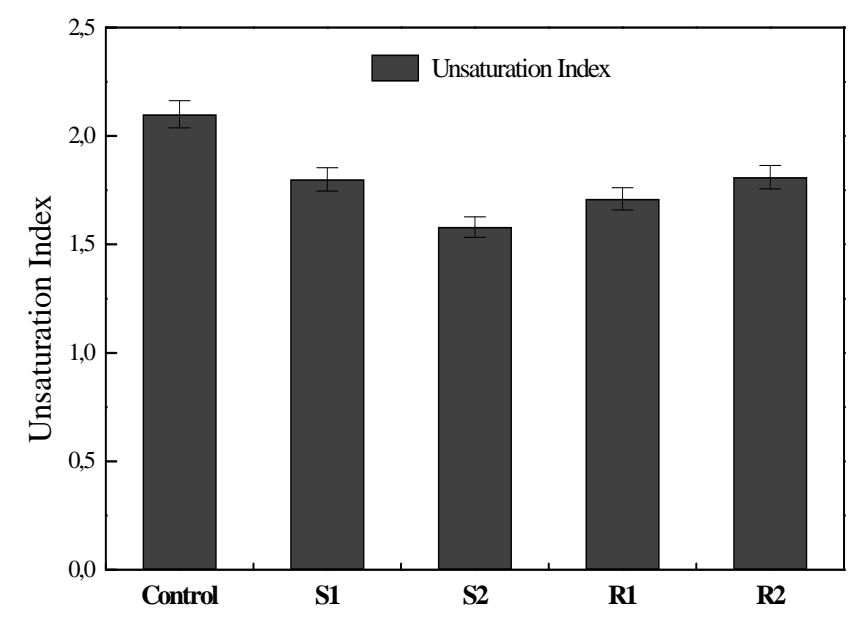

Figure 5 - Unsaturation Index from membranes lipids in Phaseolus vulgaris L. cv. Pérola leaves under Control conditions, well hydrated plants; S1, moderately stressed plants (20 days of dehydration); S2, severely stressed plants (45 days of dehydration); R1, plants rehydrated for 2 days; R2, plants rehydrated for 6 days

\section{ACKNOWLEDGEMENTS}

We thanks the PADETEC for the lipids extracts analyses, one of this work stages and the CNPq for the sponsored scholarship.

\section{RESUMO}

No presente estudo, foram utilizadas plantas de feijão (Phaseolus vulgaris L.) cv. Pérola, com a finalidade de avaliar os efeitos do déficit hídrico na condutividade elétrica, nos teores de lipídios totais e de ácidos graxos. Os resultados evidenciaram importantes efeitos da deficiência hídrica como um aumento gradativo na perda de eletrólitos. O teor de ácidos graxos saturados (ácidos palmítico e esteárico) aumentou pela ação do estresse hídrico enquanto, o teor de ácidos graxos poliinsaturados (ácidos linoléico e linolênico) e o de lipídios sofreram decréscimo. O desequilíbrio na relação ácidos graxos saturados/insaturados conduziu a uma diminuição no índice de insaturação. O aumento na perda de eletrólitos associado à redução nos teores de lipídios polares e de ácidos graxos poliinsaturados sugere maior vulnerabilidade das plantas estressadas com conseqüente perda de produtividade.

\section{REFERENCES}

Ahmed, F. E.; Hall, A. E. and Madore, M. A. (1993), Interactive effects of high temperature and elevated carbon dioxide concentration on cowpea (Vigna unguiculata (L.) Walp.). Plant Cell Environ., 16, 835-842.

Allen, C. F. and Good, P. (1971), Acyl lipids in photosynthetic systems. Methods Enzymol, 23, 523547.

Benson, A. A. (1964), Plant membrane lipids. Аnпu. Rev. Plant Physiol., 15, 1-16. 
Bigogno, C.; Khozin-Goldberg, I.; Boussiba, S.; Vonshak, A. and Cohen, Z. (2002), Lipid and fatty acid composition of the green oleaginous alga Parietochloris incisa, the richest plant source of arachidonic acid. Phytochemistry, 60, 497-503.

Chetal, S.; Wagle, D. S. and Nainawatee, H. S. (1981), Glycolipid changes in wheat and barley chloroplast under water stress. Plant Sci. Lett., 20, 225-230.

Costa Oliveira, M. S. (2001), Estudo da composição lipídica e efeito do estresse hídrico em membranas foliares de cajueiro-anão-precoce (Anacardium occidentale L.). Tese de mestrado, Universidade Federal do Ceará, Fortaleza, Brasil.

Dakhma, W. S.; Zarrouk, M. and Cherif, A. (1995), Effects of drought stress on lipids in rape leaves. Phytochemistry, 40, 1383-1386.

Dassa-Girard, M. (1987), Etude comparée des activités phosphatasiques acides et des paramètres hydriques foliaires de cultivars de mil (Pennisetum americanun L.) soumis à des contraintes hydrique. Thèse de Doctorat, Université de Paris 7, Paris, France.

Douliez, J. P. (2004), Cutin and suberin monomers are membrane perturbants. J. Colloid Interface Sci., 271, 507-510.

El-Tohamy, W.; Schnitzlerz, W. H.; El-Behairy, U. and Singer, S. M. (1999), Effect of long-term drought stress on growth and yield of bean plants (Phaseolus vulgaris L.). Appl. Bot. Angew. Bot., 73, 173 - 177.

Ferrari-Iliou, R.; Pham Thi, A. T. and Vieira da Silva, J. (1984), Effect of water stress on the lipid and fatty acid composition of cotton (Gossypium hirsutum L.) chloroplasts. Physiol. Plantarum, 62, 219-224.

Hamrouni, I.; Salah, H. B. and Marzouk, B. (2001), Effects of water-deficit on lipids of safflower aerial parts. Phytochemistry, 58, 277-280.

Ismail, A. M.; Hall, A. E. and Close, T. J. (1997), Chilling tolerance during emergence of cowpea associated with a dehydrin and slow electrolyte leakage. Crop Sci. 37, 1270-1277.

Ismail, A. M.; Hall, A. E. and Ehlers, E. J. (2000), Delayed leaf senescence and heat tolerance traits mainly are independently expressed in cowpea. Crop Sci., 40, 1049-1055.

James, A. T.; Nichols, B. W. (1966), Lipids of photosynthetic systems. Nature, 210, 372-375.

Kizis, D.; Lumbreras, V. and Pages, M. (2001), Role of AP2/EREBP transcription factors in gene regulation during abiotic stress. FEBS Lett., 498, 187-189.

Kramer, P. J. and Boyer, J. S. (1995), Water relations of plants and soils. San Diego: Academic Press, pp. 495.
Lauriano, J. A.; Lidon, F. C.; Carvalho, C. A.; Campos, P. S. and Matos, M. C. (2000), Drought effects on membrane lipids and photosynthetic activity in different peanut cultivars. Photosynthetica, 38, 7-12.

Lepage, M. (1967), Identification and composition of turnip root lipids. Lipids, 2, 244-250.

Liljenberg, C. S. (1992), The effects of water deficit stress on plant membrane lipids. Prog. Lipid Res., 31, 335-343.

Marrink, S. J.; Tieleman, D. P.; Buuren, A. R. and Berendsen, J. C. (1996), Membranes and water: An interesting relationship. Faraday Discus., 103, 191201.

Martin, B. A.; Schoper, J. B. and Rinne, R. W. (1986), Changes in soybean (Glycine max [L.] Merr.) glycerolipids in response to water stress. Plant Physiol., 81, 798-801.

Monteiro de Paula, F.; Pham Thi, A. T.; Vieira da Silva, J.; Justin, A. M.; Demandre, C. and Mazliak, P. (1990), Effects of water stress on the molecular species composition of polar lipids from Vigna unguiculata leaves. Plant Sci., 66, 185-193.

Monteiro de Paula, F.; Pham Thi, A. T.; Zuily-Fodil, Y.; Ferrari-Iliou, R.; Vieira da Silva, J. and Mazliak, P. (1993), Effects of water stress on the biosynthesis and degradation of poly-unsaturated lipid molecular species in leaves of Vigna unguiculata. Plant Physiol. Biochem., 31, 707-715.

Navari-Izzo, F.; Quartacci M. F. and Izzo, R. (1989), Lipid changes in maize seedlings in response to field water deficits. J. Exp. Bot., 40, 675-680.

Pham Thi, A. T.; Borrel-Flood, C.; Vieira da Silva, J.; Justin, A. M. and Mazliak, P. (1985), Effects of water stress on lipid metabolism in cotton leaves. Phytochemistry, 24, 723-727.

Pham Thi, A. T.; Borrel-Flood, C.; Vieira da Silva, J.; Justin, A. M. and Mazliak, P. (1987), Effects of drought on [1-C-14]-oleic and [1-C-14]-linoleic acid desaturation in cotton leaves. Physiol. Plant., 69, 147-150.

Sajo, M. D. and Machado, S. R. (2001), Submicroscopical features of leaves of Xyris species. Braz. Arch. Biol. Tech., 44, 405-410.

Scholander, P. F.; Hammel, H. T.; Hemmingsen, E. A. and Bradstreet, E. D. (1964), Hydrostatic pressure and osmotic potential in leaves of mangroves and some other plants. Proc. Natl. Acad. Sci. U.S.A., 52, 119-125.

Thiaw, S. and Hall, A. E. (2004), Comparison of selection for either leaf electrolyte leakage or pod set in enhancing heat tolerance and grain yield of cowpea. Field Crops Res., 86, 239-253. 